\title{
Role of Insulin in the Regulation of Leucine Kinetics in
}

\section{the Conscious Dog}

\author{
Naji N. Abumrad, L. S. Jefferson, S. R. Rannels, P. E. Williams, \\ A. D. Cherrington, and W. W. Lacy, Departments of Surgery, Medicine, \\ and Physiology, Vanderbilt University School of Medicine, Nashville, \\ Tennessee 37232; Department of Physiology, University of Pennsylvania, \\ Hershey, Pennsylvania 17033
}

A B S T R A C T To study the effect of insulin on leucine kinetics, three groups of conscious dogs were studied after an overnight fast (16-18 h). One, saline-infused group $(n=5)$, served as control. The other two groups were infused with somatostatin and constant replacement amount of glucagon; one group $(n=6)$ received no insulin replacement, to produce acute insulin deficiency, and the other $(n=6)$ was constantly replaced with $600 \mu \mathrm{U} / \mathrm{kg}$ per min insulin, to produce twice basal hyperinsulinemia. Hepatic and extrahepatic splanchnic (gut) balance of leucine and $\alpha$-ketoisocaproate (KIC) were calculated using the arteriovenous difference technique. $\mathrm{L}, 4,5,\left[{ }^{3} \mathrm{H}\right]$ Leucine was used to measure the rates (micromoles per kilogram per minute) of appearance ( $\mathrm{Ra})$ and disappearance (Rd), and clearance $(\mathrm{Cl})$ of plasma leucine (milliliters per kilogram per minute).

Saline infusion for $7 \mathrm{~h}$ resulted in isotopic steady state, where $\mathrm{Ra}$ and $\mathrm{Rd}$ were equal $(3.2 \pm 0.2 \mu \mathrm{mol} / \mathrm{kg}$ per min). Acute insulin withdrawal of 4 -h duration caused the plasma leucine to increase by $40 \%$ ( $P$ $<0.005$ ). This change was caused by a decrease in the outflow of leucine $(\mathrm{Cl})$ from the plasma, since Ra did not change. The net hepatic release of the amino acid $(0.24 \pm 0.03 \mu \mathrm{mol} / \mathrm{kg}$ per min) did not change significantly; the arterio-deep femoral venous differences of leucine $(-10 \pm 1 \mu \mathrm{mol} / \mathrm{liter})$ and $\mathrm{KIC}(-12 \pm 2 \mu \mathrm{mol} /$ liter) did not change significantly indicating net release of the amino and ketoacids across the hindlimb. Selective twice basal hyperinsulinemia resulted in a

Dr. Abumrad is the recipient of a Clinical Investigator Award (2M01-RR95) from the Division of General Clinical Centers Program, Division of Research Resources, National Institute of Health. Address reprint requests to Dr. Abumrad, Vanderbilt University Medical School, Nashville, TN 37232.

Received for publication 29 January 1982 and in revised form 22 July 1982.
$36 \%$ drop in plasma leucine (from control levels of $128 \pm 8$ to $82 \pm 7 \mu \mathrm{mol} /$ liter,$P<0.005)$ within $4 \mathrm{~h}$. This was accompanied by a $15 \%$ reduction in $\mathrm{Ra}$ and a $56 \%$ rise in clearance $(P<0.001$, both). Net hepatic leucine production and net release of leucine and KIC across the hindlimb fell markedly. These studies indicate that physiologic changes in circulating insulin levels result in a differential dose-dependent effect on total body leucine metabolism in the intact animal. Acute insulin withdrawal exerts no effect on leucine rate of appearance, while at twice basal levels, insulin inhibited leucine rate of appearance and stimulated its rate of disappearance.

\section{INTRODUCTION}

The effects of insulin on protein turnover in the intact animal $(1,2)$ or man $(3-6)$ have been primarily obtained from nitrogen balance studies. In the absence of insulin, the untreated insulin-dependent diabetic (7) or depancreatectomized dog (2) has enhanced nitrogen excretion, which is reversed with insulin replacement. These studies, however, fail to distinguish between changes in the rates of protein synthesis and degradation. In vitro studies in rat skeletal or cardiac muscles have established that insulin stimulates protein synthesis by enhancing peptide chain initiation and inhibits protein breakdown by a yet unknown mechanism (8). In the liver, insulin exerts an anticatabolic effect, primarily due to stabilization of liver lysosomes $(9,10)$. It is not clear from these studies, however, whether it is the effect of insulin on protein synthesis or degradation that predominates in vivo.

The effect of insulin on branched-chain amino acid homeostasis in the intact animal or man is not very well delineated. In high amounts, insulin suppresses the plasma concentration of most of the amino acids, 
and particularly leucine, isoleucine, and valine (3). On the other hand, in situations of relative or absolute insulin deficiency, as in obesity (7), starvation $(4,11)$, and diabetes mellitus (7) the concentrations of the branched-chain amino acids are elevated. It is not clear however, whether the changes observed in the plasma concentrations of the branched-chain amino acids are due to changes in their rates of appearance into or disappearance from the plasma compartment. Leucine, being an essential amino acid, its only source after an overnight fast must be from protein, and therefore changes in its rate of turnover in plasma will reflect changes in protein turnover. The studies presented herein were undertaken to examine the effect of physiologic changes in insulin levels on total leucine flux and on leucine balance across the hindlimb, the splanchnic and hepatic beds. To define the effects of acute insulin deficiency, independent of changes in glucagon secretion, somatostatin $(\mathrm{SRIF})^{1}$ was used to inhibit the endocrine pancreas and glucagon was replaced to basal levels via the intraportal route. The effects of twice basal insulin, i.e., hyperinsulinemia, were also examined in a similar fashion. SRIF was used to inhibit the endocrine pancreas; glucagon was replaced to basal levels, while insulin was replaced to twice basal levels via the intraportal route.

\section{METHODS}

Experiments were carried out on 17 overnight fasted mongrel dogs $(20-26 \mathrm{~kg})$ of either sex, which had been fed a regular dog chow diet (Wayne Dog Food, Allied Mill, Inc., Chicago, IL) for 3 wk before their use. Silastic catheters were implanted under general anesthesia in the portal vein, proximal splenic vein, hepatic vein, and femoral artery, as described (12), $17 \mathrm{~d}$ before the study. After the catheters were implanted they were filled with saline containing heparin $(200 \mathrm{U} / \mathrm{ml}$, Abbott Diagnostics, Diagnostic Products, North Chicago, IL) and their free ends were knotted and placed in a subcutaneous pouch so that complete closure of skin incisions was possible.

$16 \mathrm{~d}$ after surgery, blood was drawn from each animal to determine leukocyte count and hematocrit. Only animals that had a hematocrit $>38 \%$, a leukocyte count $<15,000 /$ $\mathrm{mm}^{3}$, a good appetite (consuming greater than two-thirds of their daily rations), and normal stools were used in the studies to be described. On the day of the study the catheters were removed from the subcutaneous pockets through skin incisions made under local anesthesia (1\% lidocaine, Astra Pharmaceutical Products, Inc., Worcester, MA). The contents of each catheter were aspirated and saline was infused through them at a slow rate $(0.1 \mathrm{ml} / \mathrm{min})$ until the experiment began. The portal vein, hepatic vein, and arterial catheters were used for blood sampling, while the splenic vein catheter was used for hormone infusion. Angiocatheters (No. 18 gauge, Abbott Diagnostics) were inserted percutaneously

${ }^{1}$ Abbreviations used in this paper: KIC, $\alpha$-ketoisocaproic acid; $\mathrm{Ra}$, rate of appearance of plasma leucine; Rd, rate of disappearance of plasma leucine; SRIF, somatostatin. into the two cephalic veins as well as the right saphenous vein. An angiocatheter (No. 18 gauge) was introduced into the left saphenous vein and threaded into the deep femoral vein and used for blood sampling across the hindlimb. The right and left cephalic veins were used for the $\left[{ }^{3} \mathrm{H}\right]$ leucine and cardiogreen infusion $\left(0.075 \mathrm{mg} / \mathrm{m}^{2}\right.$ per $\left.\mathrm{min}\right)$, respectively, and the saphenous vein was used for SRIF infusion. After completion of preexperimental preparation, the conscious dogs were placed in a Pavlov harness and were allowed to rest for $\sim \mathrm{l} \mathrm{h}$ before the beginning of the intravenous infusion of the tracer.

Experimental design. All experiments consisted of a 180min tracer equilibration period (from -210 to $-30 \mathrm{~min}$ ) followed by a $30 \mathrm{~min}$ basal period (from -30 to $0 \mathrm{~min}$ ) and a 240-min period of hormone perturbation (0-240 min). A constant infusion of $\mathrm{L}-4,5,\left[{ }^{3} \mathrm{H}\right]$ leucine was started at -210 min and continued throughout the study.

SRIF $(0.8 \mu \mathrm{g} / \mathrm{kg}$ per min) was infused from 0 to $240 \mathrm{~min}$ in combination with intraportal glucagon and/or insulin. Glucagon was infused at a constant rate of $0.65 \mathrm{ng} / \mathrm{kg}$ per min and insulin, when used, was infused at a constant rate of $600 \mu \mathrm{U} / \mathrm{kg}$ per min.

Three types of experiments were performed: (a) Group I $(n=5)$-saline was infused to assess the stability of the animals during the experimental period. (b) Group II ( $n$ $=6$ )-SRIF plus intraportal glucagon, to determine the effect of acute $(4 \mathrm{~h})$ selective insulin lack. (c) Group III ( $n$ $=6$ ) -SRIF plus intraportal glucagon and insulin, to examine the influence of a twofold rise in circulating insulin on leucine kinetics; during this study glucose $(50 \%$ dextrose in water) was infused at a variable rate to maintain euglycemia. The $\mathrm{L}-4,5,\left[{ }^{3} \mathrm{H}\right] l$ leucine infusion differed amongst the three groups and amounted to $(18.9 \pm 0.5) \times 10^{6},(12.8 \pm 0.6) \times 10^{6}$, and $(3.34 \pm 0.4) \times 10^{6} \mathrm{dpm} / \mathrm{min}$ for groups I, II, and III, respectively.

Processing of blood samples. Blood samples were drawn every $10 \mathrm{~min}$ throughout the basal period and every $30 \mathrm{~min}$ thereafter. The collection and immediate processing of blood samples have been described (12). In group III, plasma glucose was monitored every $15 \mathrm{~min}$ and the exogenous infusion of dextrose solution was adjusted accordingly to maintain euglycemia. Plasma immunoreactive glucagon was assayed using Unger's (13) $30 \mathrm{~K}$ antibody obtained from the University of Texas, Southwestern Medical School. Immunoreactive insulin was measured by the Sephadex-bound antibody procedure (Pharmacia Fine Chemicals, Piscataway, NJ) (14). Indocyanine green (cardiogreen) was measured spectrophotometrically at $810 \mathrm{~nm}$ for the determination of hepatic blood flow (15).

The radioactivity and the concentration of $\left[{ }^{3} \mathrm{H}\right]$ leucine in plasma samples were determined by rapid column chromatography procedure. The system consists of two identical jacketed chromatographic columns $(0.9 \mathrm{~cm}$ i.d. $)$ packed with resin BP-AN-6 (Benson Co., Reno, NV). Separate buffer pumps are used on each column and are fed from the common buffer through three-way solinoid operated valves. Flow of the two pumps is equal and the effluents from the two columns lead to a four-way valve arranged so that when one column is directed to a fraction collector through a " $T$ " fitting, the other column effluent is directed to waste. The effluent stream directed to the fraction collector is continuously sampled from the $\mathrm{T}$ fitting by an autoanalyzer (Technicon listruments Corp., Tarytown, NY) that reacts the stream with ninhydrin for quantitation of the leucine peak. The current method uses the following conditions: column height $12.2 \mathrm{~cm}$, sodium citrate buffer $(0.2 \mathrm{M})$ with $\mathrm{pH}$ of 3.24 and buffer flow rate of $2.2 \mathrm{ml} / \mathrm{min}$. Under these con- 
ditions, methionine and the branched-chain amino acids are well separated with peak time for leucine at $27 \mathrm{~min}$, depending on the $\mathrm{pH}$ of the buffer. Quantitation of leucine concentration using this method was carried out by measuring peak heights, having first established that peak height was linear with concentration. A factor was established, using leucine standards of various concentration, to convert peak heights to micromole leucine per milliliter. Radioactivity in the fraction collected during elutions of the leucine peak was determined using established liquid scintillation techniques. The disintegrations per minute per milliliter of the effluent were multiplied by the total volume of the fraction to obtain the total radioactivity in the sample applied. This was further corrected for the fractional recovery of $\left[{ }^{3} \mathrm{H}\right]$ leucine determined for each run. In addition, the specific radioactivity of $\left[{ }^{3} \mathrm{H}\right]$ leucine in the infusate solution was checked in each experiment in a similar fashion to the plasma samples. The coefficients of variation, in duplicate pairs $(n=12)$ were $2.3 \%$ for arterial plasma leucine concentration and $3.1 \%$ for leucine specific activity

The concentration of $\alpha$-ketoisocaproic acid (KIC) in plasma was measured by high performance liquid chromatography (HPLC) (16). In brief, plasma is precipitated with $0.6 \mathrm{M}$ perchloric acid and the filtrate is reacted with 2,4dinitrophenylhydrazine $(1: 1, \mathrm{vol} / \mathrm{vol})$; the filtrate is then extracted with an equal volume of cyclohexane/heptane/ ether solution (10:1:1) (17). The organic layer is removed, dried, and kept at $4^{\circ} \mathrm{C}$ overnight. The sample is then reconstituted with methanol and run on the HPLC using reverse-phase $\mathrm{C}$-18, $\mu$-Bondapak column (Waters Instruments, Inc., Rochester, MN) and eluted with $50 \mathrm{mM} \mathrm{Na}_{2} \mathrm{HPO}_{4}$ buffer, pH 7.0 at a rate of $2 \mathrm{ml} / \mathrm{min}$. The effluent is monitored spectrophotometrically at $365 \mathrm{~nm}$. This method allows the separation of ketoacids of leucine and valine, KIC, and $\alpha$-keto- $\beta$-methyl-valeric acid, at 3.5 and $4.5 \mathrm{~min}$, respectively.

Materials. L-4,5, $\left.{ }^{3} \mathrm{H}\right]$ Leucine (New England Nuclear, Boston, MA) was used as the radioactive tracer $(55 \mu \mathrm{Ci} /$ $\mu \mathrm{mol})$. The purity of the tracer was determined for each batch of $\left[{ }^{3} \mathrm{H}\right]$ leucine used; $98-99 \%$ of the radioactivity infused was in leucine. Insulin and glucagon were purchased from Eli Lilly \& Company (Indianapolis, IN); trasylol from FBA Pharmaceuticals Inc. (New York) and ${ }^{125}$ I-glucagon was obtained from Novo Research Institute (Copenhagen, Denmark). Phadebas insulin radioimmunoassay kit was purchased from Pharmacia Fine Chemicals, Inc. All hormones solutions were prepared with normal saline and contained $0.3 \%$ bovine albumin.

Tracer methods and calculations. The rates of leucine flux in and out of the plasma compartment were determined by the constant tracer infusion method. At maximal steadystate ("plateau") arterial leucine specific activity, the amount of $\left[{ }^{3} \mathrm{H}\right]$ leucine entering the pool is equivalent to the amount of leaving the pool, assuming that the pool size remains constant. Thus, under steady-state conditions, the rate of appearance ( $\mathrm{Ra}$ ) of leucine in the plasma compartment is equal to its rate of disappearance (Rd) and is equivalent to the rate of isotope infusion in disintegrations per minute per kilogram divided by the plateau arterial specific activity in disintegrations per minute per micromole per $10^{3}$. This method assumes that the reentry of isotope from the protein pool is negligible during the infusion period. Clearance $(\mathrm{Cl})$ of leucine from the plasma compartment is calculated by dividing Rd (micromoles per kilogram per $\mathrm{min}$ ) by the plasma leucine concentration (micromoles per milliliter)

During nonsteady-state conditions, calculations of the rates were carried out according to the method of Wall et al. (18) as simplified by DeBodo et al. (19). This method is based on a single compartment analysis in which is it assumed that rapid changes in the specific activity and concentration of leucine did not occur uniformly within the entire leucine pool.

Net hepatic, splanchnic and "gut" (extrahepatic splanchnic tissue) balance of leucine and other substrates were calculated as follows:

$$
\begin{aligned}
& \text { Net hepatic balance } \\
& =\left[0.72(\mathrm{HV}-\mathrm{PV})_{\text {conc }}+0.28(\mathrm{HV}-\mathrm{A})_{\text {conc }}\right] \times \mathrm{EHPF} \\
& \text { Net splanchnic balance }=(\mathrm{HV}-\mathrm{A})_{\text {conc }} \times \mathrm{EHPF} \\
& \text { Net "gut" balance }=(\mathrm{PV}-\mathrm{A})_{\text {conc }} \times 0.72 \mathrm{EHPF},
\end{aligned}
$$

where $\mathrm{A}, \mathrm{PV}$, and $\mathrm{HV}$ represent the plasma concentration of leucine in the artery, portal, and hepatic veins, respectively; EHPF represents the estimated hepatic plasma flow; it is estimated that portal vein supplies $72 \%$ and the artery $28 \%$ of the hepatic blood flow (12).

Statistical analyses were performed using the Student's $t$ test, the paired $t$ test, and, where applicable, analysis of variance. The data in the figures and tables are expressed as mean $\pm \mathrm{SEM}$.

\section{RESULTS}

Steady-state leucine kinetics. Fig. 1 shows the plasma leucine concentration and arterial leucine specific activity in the saline-infused control group. There was no significant change in plasma leucine concentration during $7 \mathrm{~h}$ of saline infusion. Leucine specific activity did not reach steady-state levels until $180 \mathrm{~min}$ after the start of the infusion. Because of this fact all studies were performed allowing a 3 -h isotopic equilibration period, a 0.5 -h basal period, followed by a perturbation period as outlined in the experimental design.

To establish whether SRIF has any effect on leucine metabolism and kinetics in the conscious dog, we measured plasma leucine concentration and flux in two overnight fasted dogs for $6 \mathrm{~h}$. When SRIF was infused with intraportal replacement of basal insulin $(225 \mu \mathrm{U} /$ $\mathrm{kg}$ per $\mathrm{min}$ ) and glucagon ( $0.65 \mathrm{ng} / \mathrm{kg}$ per $\mathrm{min})$, plasma leucine $(113 \pm 3 \mu \mathrm{mol} / \mathrm{ml})$ and its specific activity $\left(254 \pm 21 \mathrm{dpm} / \mu \mathrm{mol}\right.$ per $\left.10^{3}\right)$ showed no significant change from saline controls (plasma leucine $=118 \pm 6 \mu \mathrm{mol} /$ liter and specific activity $=261 \pm 19$ $\mathrm{dpm} / \mu$ mol per $10^{3}$ ).

Table I summarizes the mean values of plasma leucine and KIC obtained during the basal period from the three study groups. There is a stepwise dilution of the arterial specific activity across the splanchnic bed. The portal and the hepatic vein specific activities were 22 and $36 \%$, respectively, lower than that of the artery. The dilution of the specific activity across the gut is mainly due to the exchange of labeled leucine for unlabeled molecules. This is evident by the fact that the ratio of portal venous specific activity to that of the 

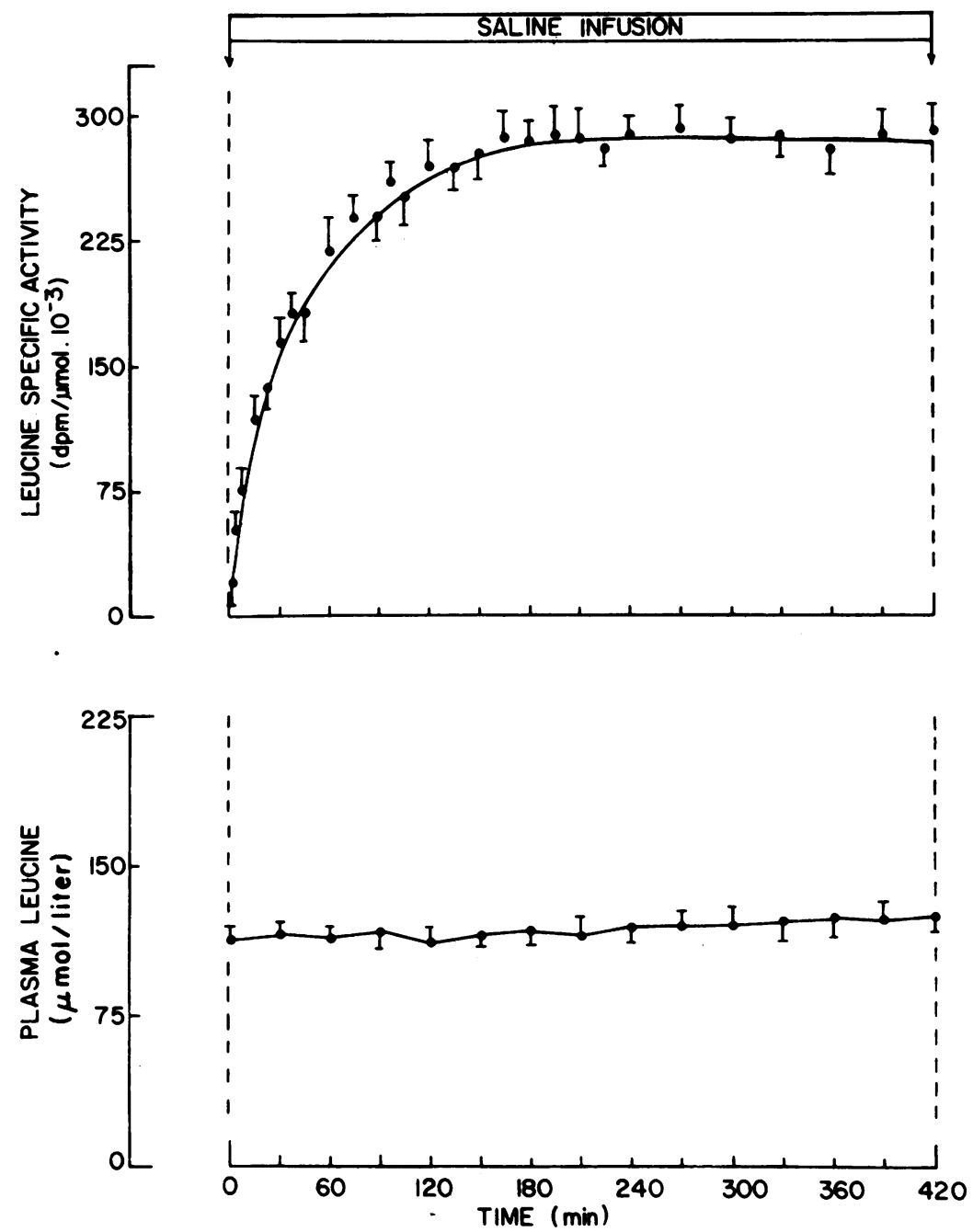

Figure 1 The arterial plasma leucine and leucine specific activity in $16-18$-h fasted conscious dogs maintained on saline infusion.

artery was $0.79 \pm 0.01$, while the ratio of plasma leucine concentrations in the two vessels was $0.95 \pm 0.01$. To determine whether exchange of label occurred across the liver during the basal period, the specific activity of leucine entering the liver was compared with that leaving the liver and the ratio was $0.78 \pm 0.02$. Because the ratio of unlabeled leucine in the hepatic vein to that entering the liver was $1.07 \pm 0.01$, then about onethird of the dilution occurring across the liver must have resulted from a net addition of unlabel'ed leucine to the plasma $(0.24 \pm 0.03 \mu \mathrm{mol} / \mathrm{kg}$ per $\min , P<0.05$; Table II) and the remainder from the exchange of labeled for unlabeled molecules as plasma traversed the liver. The mean rate of $\left[{ }^{3} \mathrm{H}\right]$ leucine infusion was $591 \times 10^{3} \mathrm{dpm} / \mathrm{kg}$ per min, whereas the mean rates of hepatic and gut $\left[{ }^{3} \mathrm{H}\right]$ leucine uptake were $76.8 \times 10^{3}$ and $81.6 \times 10^{3} \mathrm{dpm} / \mathrm{kg}$ per min, respectively. Thus,
$27 \pm 3 \%$ of the infused label was removed by the splanchnic bed $(14 \pm 2 \%$ by the gut and $13 \pm 2 \%$ by the liver) indicating that $\sim 70 \%$ of leucine flux out of the plasma compartment occurred in the extrasplanchnic tissues.

Plasma leucine concentrations in the three vessels were four-to sevenfold higher than those of KIC. The concentrations were such that there was a consistent net hepatic uptake of $\mathrm{KIC}(0.20 \pm 0.08 \mu \mathrm{mol} / \mathrm{kg}$ per $\mathrm{min})$ and an equivalent net hepatic output of leucine $(0.24 \pm 0.03 \mu \mathrm{mol} / \mathrm{kg}$ per $\mathrm{min})$; the extrahepatic splanchnic tissues (the gut) extracted both KIC and leucine (Table II). Although these values were very small, they were all statistically significant $(P<0.05)$. Arteriovenous differences across the hindlimb were $-10 \pm 1$ and $-12 \pm 2 \mu \mathrm{mol} /$ liter for both leucine and KIC, respectively. Despite this net release of the amino 
TABLE I

Mean Plasma Leucine Levels in the Basal Period of Overnight

Fasted (16-18 h) Conscious Dogs ${ }^{\circ}$

\begin{tabular}{llc}
\hline & \multicolumn{1}{c}{ Leucine } & KIC \\
\hline Arterial concentration $(\mu \mathrm{mol} / \mathrm{liter})$ & $130 \pm 4(17)$ & $31 \pm 4(9)$ \\
Portal vein concentration $(\mu \mathrm{mol} / \mathrm{liter})$ & $124 \pm 4(17)$ & $24 \pm 5(9)$ \\
Hepatic vein concentration $(\mu \mathrm{mol} / \mathrm{liter})$ & $138 \pm 5(17)$ & $20 \pm 3(9)$ \\
Arterial specific activity $\left(\mathrm{dpm} / \mu \mathrm{mol} / 10^{3}\right)$ & $171 \pm 25(17)$ & - \\
Portal vein specific activity $\left(\mathrm{dpm} / \mu \mathrm{mol} / 1 \mathrm{O}^{3}\right)$, & $133 \pm 19(17)$ & - \\
Hepatic vein specific activity $\left(\mathrm{dpm} / \mu \mathrm{mol} / 10^{3}\right)$ & $109 \pm 15(17)$ & - \\
Ratio of plasma $\left[{ }^{3} \mathrm{H}\right]$ leucine specific activity & & - \\
$\quad$ entering and exiting the liver $\downarrow$ & $0.78 \pm 0.02(17)$ & - \\
Ra $(\mu \mathrm{mol} / \mathrm{kg} / \mathrm{min})$ & $3.11 \pm 0.12(17)$ & - \\
$\mathrm{Rd}(\mu \mathrm{mol} / \mathrm{kg} / \mathrm{min})$ & $3.12 \pm 0.12(17)$ & \\
\hline
\end{tabular}

- For each dog, the four values obtained during the basal period were averaged. The number in parentheses denote the number of dogs studied. The mean weight of the dogs in three groups was $21.5 \pm 0.5 \mathrm{~kg}$. The values are expressed as mean $\pm \mathrm{SEM}$.

$\$$ The inflowing specific activity was calculated as follows: $\left(0.28 C_{A}+0.72 C_{P}\right)$ divided by $\left(0.28 R_{A}+0.72 R_{P}\right)$, where $C$ is the concentration of leucine in micromoles per liter and $R$ is leucine radioactivity in disintegrations per minute per milliliter; (A) denotes arterial plasma and (P) denotes portal plasma.

and ketoacids, there was net extraction of $\left[{ }^{3} \mathrm{H}\right]$ leucine $16 \pm 1.2 \%$ as it traversed the hindlimb (data not shown).

Effects of insulin on leucine kinetics. Fig. 2 shows the plasma insulin and glucagon concentrations for the three experimental groups. The intraportal replacement of glucagon resulted in comparable glucagon levels to those obtained in the saline-infused control group. When insulin was not infused, there was an $80 \%$ drop in plasma insulin from basal values of $12 \pm 1$ to $2 \pm 1 \mu \mathrm{U} / \mathrm{ml}(P<0.001)$ during the experimental period; the radioimmunoassay used for insulin measurement does not distinguish these latter values from zero. Infusion of intraportal insulin $(600 \mu \mathrm{U} / \mathrm{kg}$ per $\mathrm{min})$ resulted in just over a twofold $(28 \pm 2 \mu \mathrm{U} / \mathrm{ml}$, $P<0.001$ ) increase in the peripheral insulin levels.

The effect of selective changes in basal insulin on leucine metabolism can be seen in Fig. 3. The acute withdrawal of insulin resulted in a progressive increase in plasma leucine, from the basal values of $131 \pm 9$ to $187 \pm 12 \mu \mathrm{mol} /$ liter $(P<0.005)$ by the end of $4 \mathrm{~h}$. No significant change in arterial leucine specific activity was observed during this period as shown in panel $B$. On the other hand, selective hyperinsulinemia resulted in rapid changes in leucine metabolism, such that plasma leucine fell by $36 \%$ (from basal levels of $128 \pm 8$ to $82 \pm 7 \mu \mathrm{mol} /$ liter by $240 \mathrm{~min}, P<0.005)$ and leucine specific activity rose by $21 \%$ (from basal values of $44 \pm 5$ $\mathrm{dpm} / \mu \mathrm{mol}$ per $10^{3}$ to $53 \pm 9 \mathrm{dpm} / \mu \mathrm{mol}$ per $10^{3}$, $P<0.005$ ).

The effect of physiologic changes in insulin levels on the rates of appearance and disappearance of leucine into and out of the plasma compartment are shown in Table III. In animals that received only saline, there was no significant change in Ra during the course of the experiment. Similarly there was no significant change in $\mathrm{Ra}$ with acute induction of insulin deficiency. In contrast, the induction of hyperinsulinemia resulted in a decline in $\mathrm{Ra}$, such that after 60 $\mathrm{min}$ it had fallen by $15 \%$ (from $3.2 \pm 0.1 \mu \mathrm{mol} / \mathrm{kg}$ per min during the basal period to $2.73 \pm 0.15 \mu \mathrm{mol} / \mathrm{kg}$ per $\min , P<0.001)$ and remained depressed for the rest of the experimental period. The clearance of leucine from the plasma compartment (Table III) dropped significantly when insulin was withdrawn (from $25 \pm 3$ $\mathrm{ml} / \mathrm{kg}$ per min during the basal period to $15 \pm 0.3 \mathrm{ml} /$ $\mathrm{kg}$ per min by the end of $4 \mathrm{~h}, P<0.00 \mathrm{i}$ ), while with hyperinsulinemia, there was a $65 \%$ rise in clearance (from $26 \pm 6$ to $42 \pm 2 \mathrm{ml} / \mathrm{kg}$ per min by $4 \mathrm{~h}, P<0.001$ ). The changes in $R d$ were such that $R a$ minus $R d$ was always positive with insulin deficiency and always negative with hyperinsulinemia (Fig. 4). These changes were not significant at any particular interval, however, the cumulative changes over the entire experimental period (i.e., $4 \mathrm{~h}$ ) were significant in both groups (cumulative Ra-Rd was $+0.58 \pm 0.08 \mu \mathrm{mol} / \mathrm{kg}$ per min with insulin deficiency and $-0.69 \pm 0.12 \mu \mathrm{mol} / \mathrm{kg}$ per min with twice basal hyperinsulinemia, $P<0.001$ for both). No significant changes were observed for the saline-infused control group.

Saline infusion or acute insulin withdrawal for $4 \mathrm{~h}$, 
TABLE II

Leucine and KIC Balance Across the Hindlimb, Gut, Splanchnic, and Hepatic Beds of Overnight Fasted (16-18 h) Conscious Dogs ${ }^{\circ}$

\begin{tabular}{|c|c|c|c|c|}
\hline & \multirow{2}{*}{$\frac{\text { Basal period }}{\text { Saline }}$} & \multicolumn{3}{|c|}{ Experimental period } \\
\hline & & Saline & No insulin & Twice insulin \\
\hline \multicolumn{5}{|l|}{ Leucine } \\
\hline $\begin{array}{c}\text { Net hepatic balance } \\
(\mu \mathrm{mol} / \mathrm{kg} / \mathrm{min})\end{array}$ & $\begin{array}{c}-0.24 \pm 0.03 \ddagger \\
(17)\end{array}$ & $\begin{array}{c}-0.25 \pm 0.04 \ddagger \\
(5)\end{array}$ & $\begin{array}{c}-0.29 \pm 0.05 \ddagger \\
(6)\end{array}$ & $\begin{array}{c}-0.04 \pm 0.04 \S \\
(6)\end{array}$ \\
\hline $\begin{array}{l}\text { Net splanchnic balance } \\
\quad(\mu \mathrm{mol} / \mathrm{kg} / \mathrm{min})\end{array}$ & $\begin{array}{c}-0.16 \pm 0.03 \ddagger \\
(17)\end{array}$ & $\begin{array}{c}-0.19 \pm 0.03 \ddagger \\
(5)\end{array}$ & $\begin{array}{c}-0.19 \pm 0.04 \ddagger \\
(6)\end{array}$ & $\begin{array}{c}-0.05 \pm 0.03 \S \\
(6)\end{array}$ \\
\hline $\begin{array}{l}\text { Net gut balance } \\
\qquad(\mu \mathrm{mol} / \mathrm{kg} / \mathrm{min})\end{array}$ & $\begin{array}{c}+0.09 \pm 0.01 \ddagger \\
(17)\end{array}$ & $\begin{array}{c}+0.07 \pm 0.03 \ddagger \\
(5)\end{array}$ & $\begin{array}{c}+0.10 \pm 0.0 \ddagger \\
(6)\end{array}$ & $\begin{array}{c}+0.09 \pm 0.01 \ddagger \\
(6)\end{array}$ \\
\hline $\begin{array}{l}\text { Hindlimb A-DV differences } \\
\quad(\mu \mathrm{mol} / \text { liter })\end{array}$ & $\begin{array}{c}-10 \pm 11 \\
(9)\end{array}$ & $\begin{array}{c}-13 \pm 2 \ddagger \\
(3)\end{array}$ & $\begin{array}{c}-14 \pm 2 t \\
(3)\end{array}$ & $\begin{array}{c}-2 \pm 18 \\
(3)\end{array}$ \\
\hline \multicolumn{5}{|l|}{ KIC } \\
\hline $\begin{array}{l}\text { Net hepatic balance } \\
(\mu \mathrm{mol} / \mathrm{kg} / \mathrm{min})\end{array}$ & $\begin{array}{c}+0.20 \pm 0.08 \ddagger \\
(17)\end{array}$ & $\begin{array}{c}+0.21 \pm 0.061 \\
(5)\end{array}$ & $\begin{array}{c}+0.15 \pm 0.04 \rrbracket \\
(6)\end{array}$ & $\begin{array}{c}+0.20 \pm 0.09 \ddagger \\
(6)\end{array}$ \\
\hline $\begin{array}{l}\text { Net splanchnic balance } \\
\quad(\mu \mathrm{mol} / \mathrm{kg} / \mathrm{min})\end{array}$ & $\begin{array}{c}+0.37 \pm 0.07 \downarrow \\
(17)\end{array}$ & $\begin{array}{c}+0.39 \pm 0.06 \ddagger \\
(5)\end{array}$ & $\begin{array}{c}+0.30 \pm 0.05 \ddagger \\
(6)\end{array}$ & $\begin{array}{c}+0.34 \pm 0.06 ! \\
(6)\end{array}$ \\
\hline $\begin{array}{l}\text { Net gut balance } \\
\qquad(\mu \mathrm{mol} / \mathrm{kg} / \mathrm{min})\end{array}$ & $\begin{array}{c}+0.17 \pm 0.04 \pm \\
(17)\end{array}$ & $\begin{array}{c}+0.18 \pm 0.05 \ddagger \\
(5)\end{array}$ & $\begin{array}{c}+0.15 \pm 0.04 \rrbracket \\
(6)\end{array}$ & $\begin{array}{c}+0.14 \pm 0.04 \ddagger \\
(6)\end{array}$ \\
\hline $\begin{array}{l}\text { Hindlimb A-DV differences } \\
(\mu \mathrm{mol} / \text { liter })\end{array}$ & $\begin{array}{c}-12 \pm 2 \ddagger \\
(9)\end{array}$ & $\begin{array}{c}-13 \pm 21 \\
(3)\end{array}$ & $\begin{array}{c}-16 \pm 3 \ddagger \\
(3)\end{array}$ & $\begin{array}{l}0 \pm 2 \S \\
(3)\end{array}$ \\
\hline
\end{tabular}

\footnotetext{
- For each dog, the four values obtained during the basal period and the five values during the last $2 \mathrm{~h}$ of the experimental period were averaged. The values during the basal period did not differ among the three study groups and the values were pooled. The numbers in parentheses denote the number of dogs studied. $(-)$ denotes release and $(+)$ denotes uptake. All values are expressed as mean \pm SEM.

$f P<0.05$.

$\$ P<0.05$.

A-DV differences, arterio-deep femoral venous differences of leucine.
}

had no effect on the net balance of KIC and leucine across the liver, gut, or hindlimb as shown in Table II. Twice basal hyperinsulinemia resulted in a significant reduction in net hepatic output of leucine (to $0.04 \pm 0.04 \mu \mathrm{mol} / \mathrm{kg}$ per min during the last $2 \mathrm{~h}$ of the infusion), while net hepatic uptake of KIC persisted of $0.20 \pm 0.09 \mu \mathrm{mol} / \mathrm{kg}$ per $\min (P<0.05)$; the specific activity of $\left[{ }^{3} \mathrm{H}\right]$ leucine in the hepatic vein increased from $34 \pm 5 \mathrm{dpm} / \mu \mathrm{mol}$ per $10^{3}$ in the basal period to $42 \pm 6 \mathrm{dpm} / \mu \mathrm{mol}$ per $10^{3}$ by $4 \mathrm{~h}$ of insulin infusion. Concomitantly, arterio-deep femoral venous differences of leucine and KIC were $-2 \pm 1$ and $0 \pm 2 \mu \mathrm{mol} /$ liter, respectively, indicating a marked reduction in the net release of the amino and ketoacids across the hindlimb.

The effect of saline and hormone infusion on plasma glucose were consistent with those previously reported from this laboratory (22). During the saline control, and during the infusion of SRIF plus intraportal re- placement of basal insulin and glucagon, plasma glucose levels remained stable. With twice basal hyperinsulinemia, euglycemia was maintained by an infusion of exogenous glucose. Selective insulin deficiency resulted in plasma glucose levels of $150-170 \mathrm{mg} \%$, which over a period of $4 \mathrm{~h}$ progressively dropped to $120 \pm 4 \mathrm{mg} \%$ (or $23 \pm 2 \mathrm{mg} \%$ above basal values).

\section{DISCUSSION}

This study addresses the effects of physiologic changes in insulin concentrations on leucine metabolism in the intact animal, with special reference to the role of basal insulin in maintaining normal whole body protein homeostasis. Furthermore, the combination of the arteriovenous difference and isotopic techniques used in the present study provided valuable information regarding leucine flux that could not be obtained by either technique alone. 


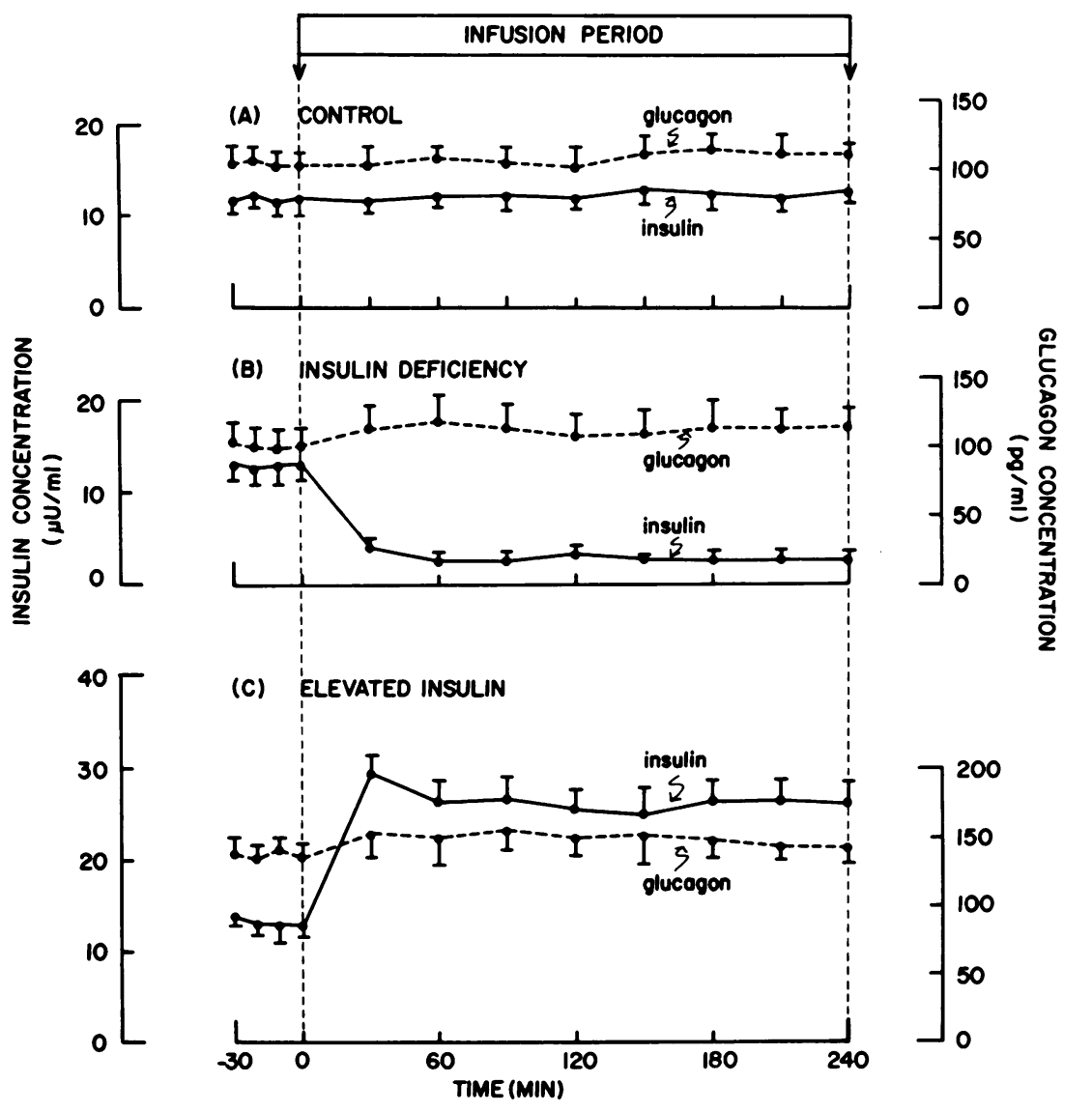

FIGURE 2 The arterial plasma insulin and glucagon levels during saline infusion (panel A) or during the infusion of SRIF $(0.8 \mu \mathrm{g} / \mathrm{kg}$ per min) and concurrent intraportal inf usion of glucagon $(0.65 \mathrm{ng} / \mathrm{kg}$ per min) alone (as in panel B) or with insulin $(600 \mu \mathrm{U} / \mathrm{kg}$ per min) (as in panel C).

The flux of an amino acid, defined as the rate of entry or exit from a pool can be estimated by the continuous infusion of the isotopically labeled amino acid. At steady state, the rate of appearance ( $\mathrm{Ra})$, or its equivalent the rate of irreversible disposal (Rd) can be calculated using the plateau-specific activity of the labeled moiety in the infused pool regardless of the volume of the pool or the configuration of the system. $\mathrm{Ra}$ determined in this fashion measures the rate of input of unlabeled substrate into the infused pool and does not necessarily represent the total rate of production (20). In the current study, we have measured the influx of unlabeled leucine into the plasma pool from all sources. The leucine turnover rates measured during the basal period in all three groups of dogs were in agreement with those previously reported by us (11) and by others (21).

Additionally, the application of the arteriovenous difference technique across the splanchnic bed and the hindlimb allows us to calculate the contribution of these tissues to total leucine turnover. During the steady-state control period, $\sim 30 \%$ of the infused tracer was extracted across the splanchnic bed; half by the liver and the other half by the gut. This is slightly lower than alanine flux, of which $>50 \%$ is accounted for by the splanchnic bed and particularly by the gut (22). During the transit of blood from the artery to the deep femoral vein, there was a net release of leucine; this was accompanied by a net extraction of leucine radioactivity showing a process of exchange occurring across the hindlimb. If we assume that plasma flow was $0.101 \mathrm{liter} / \mathrm{min}(21)$, then from the change in the specific activities of the artery $(122 \pm 25 \mathrm{dpm} / \mu \mathrm{mol}$ per $\left.10^{3}\right)$ and the deep veins $\left(95 \pm 20 \mathrm{dpm} / \mu \mathrm{mol}\right.$ per $\left.10^{3}\right)$, at least $36 \%$ of the dilution occurring across the hindlimb must have resulted from the net addition of nonradioactive leucine to plasma.

The small, but consistent net release of leucine from the splanchnic bed and the hindlimb, raises an interesting question concerning the site of net consumption 


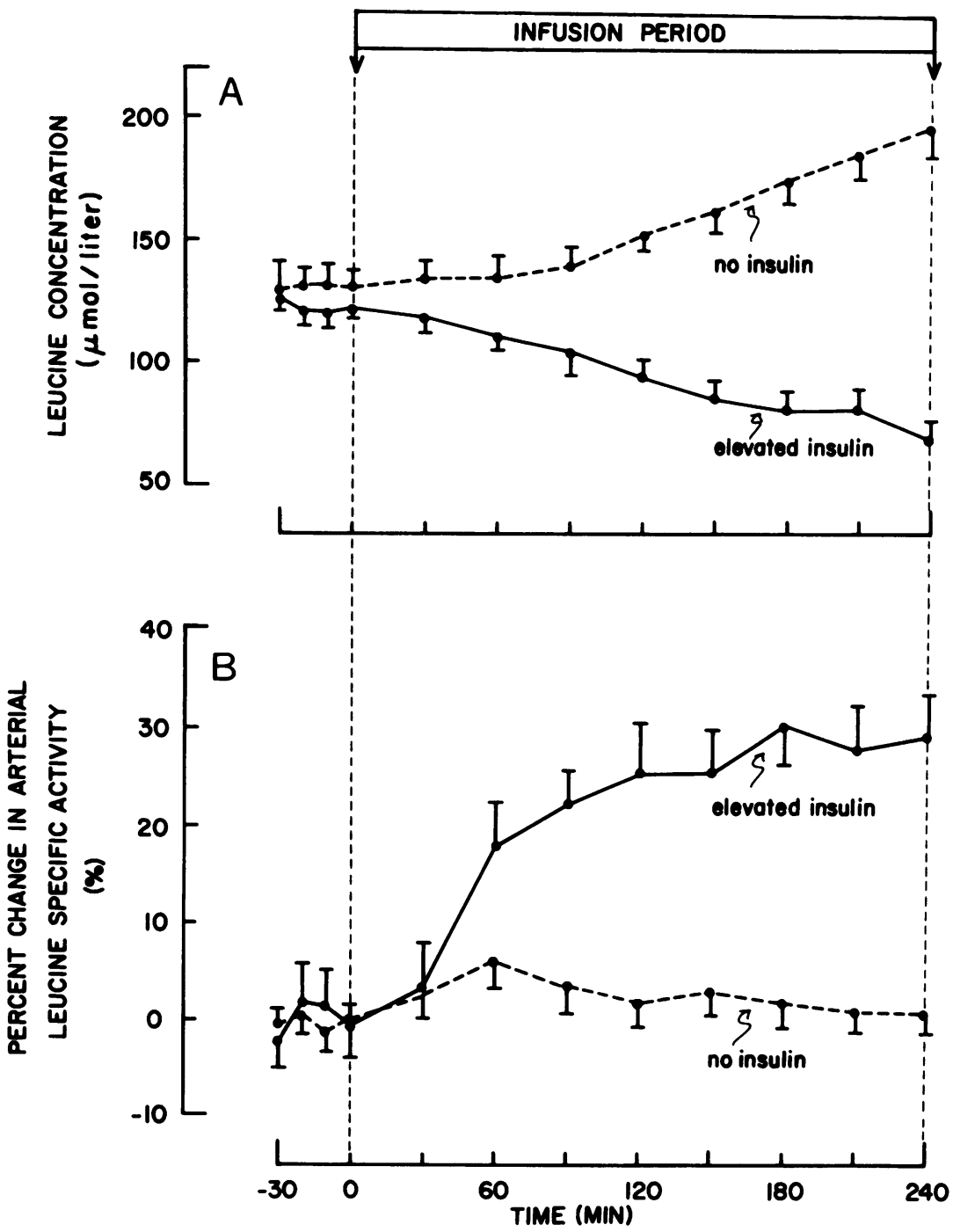

Figure 3 The arterial plasma leucine concentration and the percent change from basal of leucine specific activity in 16-18-h fasted conscious dogs maintained on infusions of SRIF (0.8 $\mu \mathrm{g} / \mathrm{kg}$ per min) and concurrent intraportal infusions of glucagon alone $(0.65 \mathrm{ng} / \mathrm{kg}$ per minno insulin, broken line) or in combination with insulin $(600 \mu \mathrm{U} / \mathrm{kg}$ per min-elevated insulin, solid line). The changes in the concentration of plasma leucine from control levels were significant $(P<0.05)$ from 90 min on, when using paired or unpaired $t$ tests. The changes in leucine specific activity were significant $(P<0.05)$ only in the elevated insulin group from 60 min on (paired or unpaired $t$ tests), when compared to both saline control or no insulin groups.

of leucine. Since after an overnight fast, both muscle and splanchnic beds contribute leucine to the plasma compartment, then other sites must utilize leucine during that period. Recent data from this laboratory, obtained from a similarly fasted group of dogs, have demonstrated the capacity of the kidneys to utilize leucine at a basal rate of $0.25 \pm 0.03 \mu \mathrm{mol} / \mathrm{kg}$ per min (15). Furthermore, in vitro evidence exists for the metabolism of these amino acids by the heart (23), adipose (24), and nervous tissues (25).
With the use of isotope tracers, a precise quantification of protein synthesis and degradation cannot be made from plasma specific activities alone. Assumptions about the relation of the plasma to the intracellular specific activities in the different tissues must be made, or an independent estimate of the precursor pool specific activity is required. Despite these limitations, changes in the rate of appearance of leucine into the plasma compartment should reflect changes in protein degradation; this is based on the fact that 
TABLE III

Effect of Physiologic Changes in Insulin Levels on Plasma Leucine Turnover in the Conscious, Overnight (16-18 h)-Fasted Dogs ${ }^{\circ}$

\begin{tabular}{|c|c|c|c|c|c|c|c|c|c|}
\hline \multirow[b]{2}{*}{ Time interval } & \multicolumn{3}{|c|}{ Saline control $(n=5)$} & \multicolumn{3}{|c|}{ No insulin (n=6) } & \multicolumn{3}{|c|}{ Twice insulin $(n=6)$} \\
\hline & $\mathbf{R a}$ & Rd & Clearance & $\mathbf{R a}$ & Rd & Clearance & $\mathbf{R a}$ & Rd & Clearance \\
\hline $\min$ & \multicolumn{2}{|c|}{$\mu \mathrm{mol} / \mathrm{kg}$ per $\min$} & $\mathrm{ml} / \mathrm{kg} / \min$ & \multicolumn{2}{|c|}{$\mu \mathrm{mol} / \mathrm{kg}$ per min } & $\mathrm{ml} / \mathrm{kg} / \min$ & \multicolumn{2}{|c|}{$\mu \mathrm{mol} / \mathrm{kg}$ per $\min$} & $\mathrm{ml} / \mathrm{kg} / \mathrm{min}$ \\
\hline \multicolumn{10}{|c|}{ Basal period } \\
\hline$-30-0$ & $3.11 \pm 0.19$ & $3.18 \pm 0.15$ & $25 \pm 2$ & $3.08 \pm 0.17$ & $3.05 \pm 0.10$ & $25 \pm 3$ & $3.19 \pm 0.09$ & $3.22 \pm 0.12$ & $26 \pm 2$ \\
\hline \multicolumn{10}{|c|}{ Experimental period } \\
\hline $0-30$ & $3.18 \pm 0.16$ & $3.17 \pm 0.16$ & $24 \pm 2$ & $3.04 \pm 0.10$ & $2.83 \pm 0.11 \downarrow$ & $22 \pm 1.2$ & $3.16 \pm 0.18$ & $3.25 \pm 0.17$ & $27 \pm 2$ \\
\hline $30-60$ & $3.09 \pm 0.21$ & $3.18 \pm 0.20$ & $25 \pm 1$ & $3.08 \pm 0.14$ & $2.92 \pm 0.05 \ddagger$ & $22 \pm 1.8$ & $2.90 \pm 0.14 \rrbracket$ & $2.99 \pm 0.14$ & $28 \pm 2$ \\
\hline $60-90$ & $3.13 \pm 0.17$ & $3.10 \pm 0.18$ & $24 \pm 3$ & $2.97 \pm 0.15$ & $2.90 \pm 0.05 \ddagger$ & $21 \pm 1.7 \ddagger$ & $2.73 \pm 0.15 \ddagger$ & $2.83 \pm 0.17 \ddagger$ & $28 \pm 3 \ddagger$ \\
\hline $90-120$ & $3.15 \pm 0.16$ & $3.14 \pm 0.16$ & $26 \pm 3$ & $2.94 \pm 0.17$ & $2.86 \pm 0.09 \rrbracket$ & $19 \pm 1.0 \ddagger$ & $2.70 \pm 0.15 \rrbracket$ & $2.76 \pm 0.16 \rrbracket$ & $30 \pm 3 \ddagger$ \\
\hline $120-150$ & $3.16 \pm 0.14$ & $3.13 \pm 0.16$ & $23 \pm 4$ & $3.03 \pm 0.13$ & $2.95 \pm 0.11$ & $18 \pm 0.8 \rrbracket$ & $2.76 \pm 0.15 \ddagger$ & $2.81 \pm 0.18 \ddagger$ & $35 \pm 2 \ddagger$ \\
\hline $150-180$ & $3.19 \pm 0.17$ & $3.24 \pm 0.21$ & $24 \pm 2$ & $3.05 \pm 0.13$ & $2.97 \pm 0.13$ & $17 \pm 0.5 \ddagger$ & $2.76 \pm 0.16 \rrbracket$ & $2.83 \pm 0.16 \ddagger$ & $36 \pm 2 \ddagger$ \\
\hline $180-210$ & $3.20 \pm 0.16$ & $3.22 \pm 0.20$ & $25 \pm 3$ & $3.22 \pm 0.16$ & $3.05 \pm 0.10$ & $16 \pm 0.5 \ddagger$ & $2.78 \pm 0.14 \ddagger$ & $2.92 \pm 0.15 \ddagger$ & $39 \pm 1 \ddagger$ \\
\hline $210-240$ & $3.18 \pm 0.18$ & $3.14 \pm 0.15$ & $25 \pm 2$ & $3.18 \pm 0.14$ & $2.98 \pm 0.10$ & $15 \pm 0.3 \ddagger$ & $2.71 \pm 0.14 \rrbracket$ & $2.85 \pm 0.13 \ddagger$ & $42 \pm 2 \ddagger$ \\
\hline
\end{tabular}

- Saline, SRIF plus basal intraportal glucagon, or SRIF, basal intraportal glucagon, and twice basal insulin were infused from 0 to 240 min. All values are expressed as mean \pm SEM.

I Significance from corresponding values in the basal period, $P<0.05$.

leucine is an essential amino acid and its only source after an overnight fast must be from protein.

During the period of hormonal perturbations, with changing concentration and/or specific activity, another caveat needs to be kept in mind; namely, that calculations of $\mathrm{Ra}, \mathrm{Rd}$, and clearance are dependent on the assumed volume of distribution. However, although assumption of an incorrect volume of distribution would introduce errors in the absolute values for $\mathrm{Ra}, \mathrm{Rd}$, and clearance it would not change either the direction of changes of these parameters or the relative contribution of each to the observed changes in leucine flux into and out of the plasma compartment. Keeping these considerations in mind, one can draw valid conclusions about the effect of changes in insulin concentration on the relative contribution of changes in $\mathrm{Ra}, \mathrm{Rd}$, and clearance on the flux of plasma leucine and by inference on protein degradation and synthesis.

The data obtained using the arteriovenous difference technique represent a balance between the factors influencing protein synthesis and protein breakdown across the appropriate beds. The net negative nitrogen balance observed across both skeletal muscle and splanchnic beds of 18 -h fasted dogs, similar to those previously observed across the human forearm (28-30), suggest that at basal levels, insulin has a function to maintain protein synthesis slightly less than that of protein breakdown.

During acute insulin withdrawal, the isotopic data indicated that the rise in plasma leucine was not due to an increase in leucine rate of appearance in the plasma compartment but to a relative decrease in its rate of disappearance out of plasma (Fig. 4). However, we cannot rule out the possibility that a minimum increase in Ra did occur, which in the present study would have been masked by a slight increase in recycling of ${ }^{3} \mathrm{H}$-label from the protein compartment. Nevertheless, most of the observed change was mainly due to the $40 \%$ decrement in leucine clearance (Table III). Since the observed changes in plasma leucine concentrations over the 4-h experimental period would only require the net addition of $0.06 \mu \mathrm{mol} / \mathrm{kg}$ per min of leucine, the arteriovenous technique might not be sensitive enough to pick these changes.

It is apparent that the initial event in twice basal hyperinsulinemia is a rapid fall in $\mathrm{Ra}$. $\mathrm{Rd}$ also dropped in conjunction with $\mathrm{Ra}$, however, the difference between the rates of entry and outflow of leucine into and out of the circulation (denoted by Ra minus Rd in Fig. 4) had decreased significantly by the end of the 4-h infusion. Under these conditions, it could be calculated that the change of $\mathrm{Ra}$ accounted for $\sim 50 \%$ of the change in the net balance, while Rd accounted for the rest. In this regard the net output of cold leucine by the liver and of both KIC and leucine by the hindlimb became negligible; this indicates that either the uptake of leucine by these tissues had increased and/ or its release had decreased. Thus, when the findings obtained by the arteriovenous difference technique are combined with those obtained by the tracer method, they would suggest that with hyperinsulinemia, both the liver and the hindlimb tissues (most likely skeletal muscle) participate in the observed decrement in leu- 


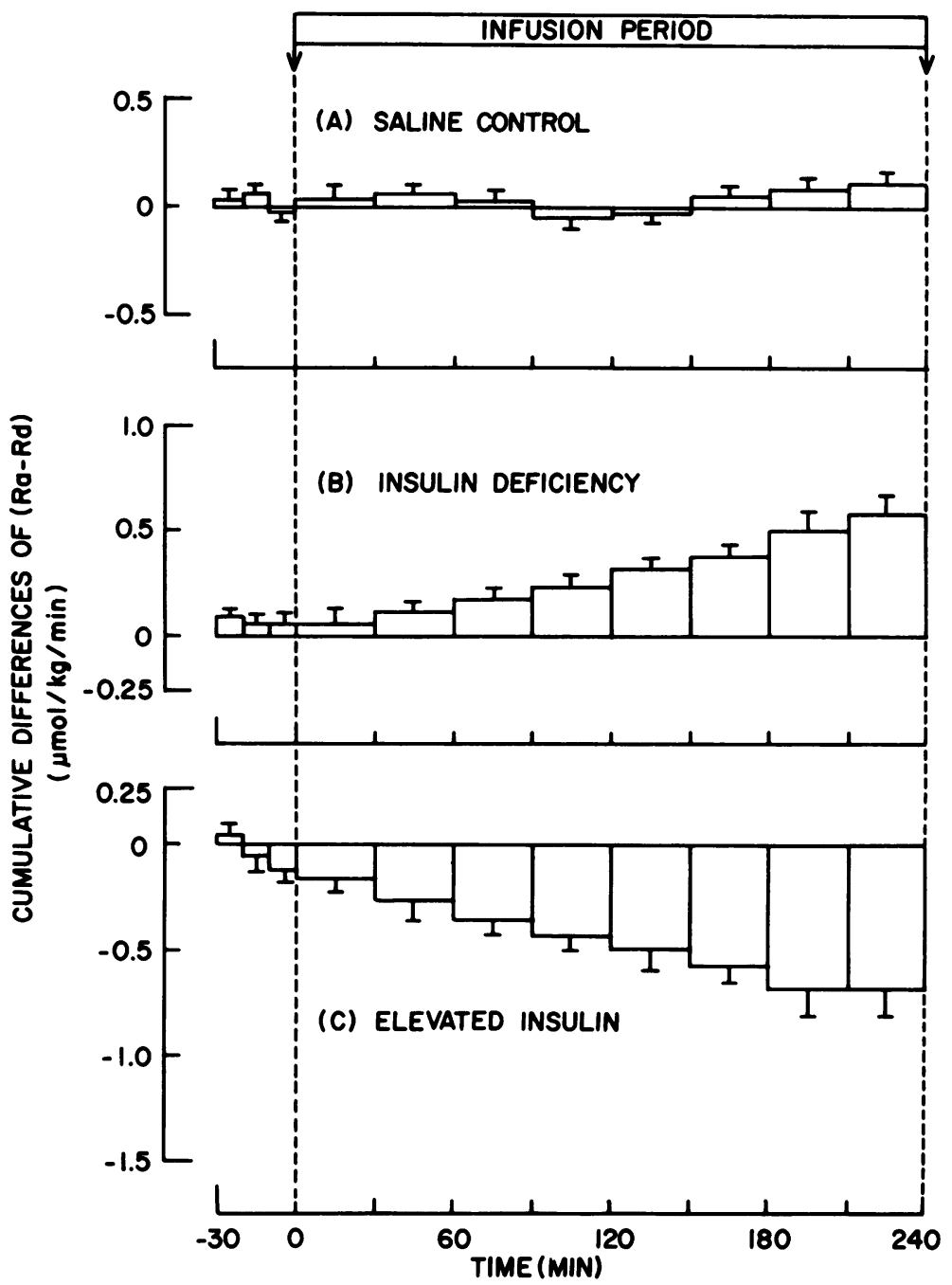

Figure 4 The cumulative differences between the rates of appearance $(\mathrm{Ra})$ and disappearance (Rd) in 16-18-h fasted conscious dogs during saline infusion or during the infusion of SRIF $(0.8 \mu \mathrm{g} / \mathrm{kg}$ per $\mathrm{min})$ and concurrent intraportal infusion of glucagon alone $(0.65 \mathrm{ng} / \mathrm{kg}$ per min-insulin deficiency), or with insulin $(600 \mu \mathrm{U} / \mathrm{kg}$ per min-elevated insulin). The values represent an average of the cumulative differences for each time period per dog and are expressed as mean \pm SEM. The number of dogs studied in each group are the same as those shown in Table III. Changes from control levels were significant $(P<0.05)$ in the insulin deficiency and elevated insulin groups, from $60 \mathrm{~min}$ on when using paired or unpaired $t$ tests.

cine rate of appearance and in the increase in its rate of clearance from the plasma compartment.

Though the rates of oxidation of leucine were not measured in the present study, it would be reasonable to assume that, if anything, leucine oxidation had increased with acute insulin withdrawal, in accordance with studies on isolated skeletal muscle preparations $(8,26)$ and declined in response to twice physiologic levels of insulin. Recent studies in man have shown that a comparable twofold rise in peripheral insulin levels have resulted in a $60 \%$ drop in leucine oxida- tion. ${ }^{2}$ Since Rd reflects changes occurring in protein synthesis and/or in the rate of leucine oxidation, it could be speculated that the initial event in selective insulin deficiency is not an increase in protein breakdown, while a slight physiologic rise in insulin may exert a dual effect on total body protein turnover, namely, an enhancement of protein synthesis and an inhibition of protein breakdown.

${ }^{2}$ Abumrad, N. N. Unpublished observations. 


\section{ACKNOWLEDGMENT}

The authors would like to acknowledge the excellent technical skills of C. L. McKinley, D. B. Lacy, S. L. Rannels, and L. L. Brown and are most grateful for the excellent secretarial skills of Rose A. Hornsby.

This investigation was supported by the Juvenile Diabetes Foundation grant 80R010, by Diabetes Research and Training Center grant AM20593, and by National Institutes of Health grant AM22195.

\section{REFERENCES}

1. Adibi, S. A., T. A. Modesto, E. L. Morse, and P. M. Amin. 1973. Amino acid levels in plasma, liver, and skeletal muscle during protein deprivation. Am. J. Physiol. 225: 408-414.

2. Atchley, D. W., R. F. Loeb, D. W. Richards, Jr., E. M. Benedict, and N. E. Driscoll. 1933. On diabetic acidosis: a detailed study of electrolyte balances following the withdrawal and re-establishment of insulin therapy. $J$. Clin. Invest. 12: 297-326.

3. Felig, P. 1975. Amino acid metabolism in man. Annu. Rev. Biochem. 44: 933-954.

4. Adibi, S. A. 1976. Metabolism of branched-chain amino acids in altered nutrition. Metab. Clin. Exp. 25: 12871302.

5. Walsh, C. H., N. G. Soler, H. James, T. C. Hatchley, B. J. Thomas, M. G. Fitzgerald, J. H. Fremcin, M. G. Fitzgerald, and J. M. Makins. 1976. Studies in whole body potassium and whole body nitrogen in newly diagnosed diabetics. Q. J. Med. (Oxford). 45: 295-301.

6. Cahill, G. 1971. Physiology of insulin in man. Diabetes. 20: 785-798.

7. Felig, P., J. Wahren, R. Hendler, and T. Brundin. 1974. Splanchnic glucose and amino acid metabolism in obesity. J. Clin. Invest. 53: 582-590.

8. Jefferson, L. S., J. B. Li, and S. R. Rannels. 1977. Regulation by insulin of amino acid release and protein turnover in the perfused rat hemicorpus. J. Biol. Chem. 252: 1476-1483.

9. Mortimore, G. E., and C. E. Mondon. 1970. Inhibition by insulin of valine turnover in liver. Evidence for a general control of proteolysis. J. Biol. Chem. 245: 23752383.

10. Ward, W. F., J. R. Cox, and G. E. Mortimore. 1977. Lysosomal sequestration of intracellular protein as a regulatory step in hepatic proteolysis. J. Biol. Chem. 252: 6955-6961.

11. Abumrad, N. N., P. E. Williams, K. L. Wise, D. B. Lacy, and $W$. W. Lacy. 1981. The effect of starvation on leucine kinetics in the conscious dog. In Metabolism and Clinical Implications of Branched-Chain Amino and Ketoacids. M. Walser and J. R. Williamson, editors. Elsevier-North Holland, Inc., New York. 355-360.

12. Keller, U., A. D. Cherrington, and J. E. Liljenquist. 1978. Ketone body turnover and net hepatic ketone production in fasted and diabetic dogs. Am. J. Physiol. 235: E238E247.

13. Aguilar-Parada, E., A. M. Eisentraut, and R. H. Unger. 1969. Pancreatic glucagon secretion in normal and diabetic subjects. Am. J. Med. Sci. 257: 415-419.

14. Wide, L., and J. Porath. 1966. Radioimmunoassay of proteins with use of Sephadex-coupled antibodies. Biochim. Biophys. Acta. 130: 255-260.

15. Leevy, C. M., C. L. Mendenhall, W. Lesko, and M. M. Howard. 1962. Estimation of hepatic blood flow with indocyanine green. J. Clin. Invest. 41: 1169-1179.

16. Abumrad, N. N., K. L. Wise, P. E. Williams, N. A. Abumrad, and W. W. Lacy. 1981. Disposal of $\alpha$-ketoisocaproate: role of liver, gut, and kidneys. Am. J. Physiol. 243: E123-E131.

17. Walser, M. P., P. Lund, N. B. Ruderman, and A. W. Coulter. 1973. Synthesis of essential amino acids from their alpha ketoanalogues by perfused rat liver and muscle. J. Clin. Invest. 52: 2865-2877.

18. Wall, J. S., R. Steele, R. C. DeBodo, and N. Altszuler. 1957. Effect of insulin on utilization and production of circulating glucose. Am. J. Physiol. 189: 43-50.

19. DeBodo, R. C., R. Steele, N. Altszuler, A. Dunn, and J. S. Bishop. 1963. On the hormonal regulation of carbohydrate metabolism: studies with $\left[{ }^{14} \mathrm{C}\right]$-glucose. Recent Prog. Horm. Res. 19: 445-488.

20. Shipley, R. A., and R. E. Clark. 1972. Tracer methods for in vivo kinetics. Academic Press, Inc., New York. 146-147.

21. Ben Galim, E., K. Hruska, D. E. Bier, and M. W. Haymond. 1980. Branched-chain amino acid nitrogen transfer to alanine in vivo in dogs. Direct isotopic determination with $\left[{ }^{15} \mathrm{~N}\right] l e u c i n e . ~ J$. Clin. Invest. 66: 1295-1304.

22. Shulman, G., W. W. Lacy, J. E. Liljenquist, U. Keller, P. E. Williams, and A. D. Cherrington. 1979. Effect of glucose, independent of changes in insulin and glucagon secretion, on alanine metabolism in the conscious dog. J. Clin. Invest. 65: 496-505.

23. Morgan, H. E., L. S. Jefferson, E. B. Wolpert, and D. E. Rannels. 1971. Regulation of protein synthesis in heart muscle. J. Biol. Chem. 246: 2163-2170.

24. Goodman, H. M. 1977. Site of action of insulin on promoting leucine utilization in adipose tissue. Am. J. Physiol. 2: E97-E103.

25. Stillway, L. W., D. A. Weigand, and M. G. Buse. 1979. Leucine as an in vitro precursor to lipids in rat sciatic nerve. Lipids. 14: 127-131.

26. Buse, M. G., H. F. Herlong, and D. A. Weigand. 1971. The effects of diabetes, insulin, and the redox potential on leucine metabolism by the isolated rat hemidiaphragm. Endocrinology. 85: 116-1175.

27. Hutson, S. M., C. Zapalowski, T. C. Cree, and A. E. Harper. 1980. Regulation of leucine and $\alpha$-ketoisocaproic acid metabolism in skeletal muscle-effects of starvation and insulin. J. Biol. Chem. 255: 2418-2426.

28. Abumrad, N. N., K. L. Wise, P. E. Williams, and W. W. Lacy. 1982. The disposition of an intravenously administered $\mathrm{L}$-amino acid solution across the human forearm. Metab. Clin. Exp. 31: 463-470.

29. Abumrad, N. N., L. Patrick, S. L. Rannels, and W. W. Lacy. 1981. Branched-chain amino acids and $\alpha$-ketoisocaproate balance across human forearm muscle. In Metabolism and Clinical Implications of Branched-Chain Amino and Ketoacids. M. Walser and J. R. Williamson, editors. Elsevier-North Holland, Inc., New York. 317322.

30. Pozefsky, T., P. Felig, J. D. Tobin, J. S. Soldener, and G. F. Cahill. 1969. Amino acid balance across tissues of the forearm in the postabsorptive man. Effects of insulin at two dose levels. J. Clin. Invest. 48: 2273-2282. 